\title{
RESEARCH ON FACTORS AFFECTING ORGANIZATIONAL STRUCTURE, OPERATING MECHANISM AND AUDIT QUALITY: AN EMPIRICAL STUDY IN VIETNAM
}

\author{
Phan T. HAI ${ }^{*}$, Chuc A. TU², Le D. TOAN 3 \\ ${ }^{1,3}$ Faculty of Accounting, Duy Tan University, Nguyen Van Linh St., \\ No. 254, Thanh Khe Dist., 55000 Da Nang, Vietnam \\ ${ }^{2}$ Faculty of Public Finance, Academy of Finance, Le Van Hien St., \\ No. 58, Bac Tu Liem Dist., 10000 Hanoi, Vietnam
}

Received 10 September 2018; accepted 25 February 2019

\begin{abstract}
This research aims to determine factors affecting and the level of their influence on organizational structure, operating mechanism and audit quality in the Vietnamese market. In this paper, the methodology used by the authors is mixed method. Combination of the qualitative research method and the quantitative research method on the basis of meta-analysis and synthesis of existing information from various sources and results of interviews carried out in early 2018 using a questionnaire for 270 auditors who now work at audit firms in Vietnam. The results of the research showed that factors affecting the operating mechanism of audit firms include the legal system, quality control and internal corporate governance. Factors affecting the audit quality are the organizational structure and the operating mechanism of audit firms. Among these factors, the operating mechanism has the greatest impact on and plays a decisive role in the audit quality. In addition, the research showed that factors affecting the organizational structure of audit firms in Vietnam are unobvious.
\end{abstract}

Keywords: independent audit, organizational structure, operating mechanisms, audit quality, audit firms, SEM, Vietnam.

JEL Classification: C12, M10, M42.

\section{Introduction}

Up to now, there has been a large number of researches on factors affecting the audit quality such as researches by DeAngelo (1981), Chadegani Aghaei (2011), Francis (2011), Al-Ajmi (2009), Lennox (2005), Favere-Marchesi (2000), etc. In Vietnam, the issue of audit quality and factors affecting the audit quality is not new. The issue is dealt with in many researches by Vietnamese authors, especially the research on relationship of regulatory organizations and independent audit supervision organizations with audit firms and audit quality (Duc,

${ }^{*}$ Corresponding author. E-mail: phanthanhhai@duytan.edu.vn 
2002), the research on the fact that Vietnamese audit firms are members of international audit firms has an influence on the audit quality (Ha, 2012), the research on audit fees, audit firm size, reputation and audit quality (Pham, Duong, Pham, \& Ho, 2017), and the research on audit quality control inside and outside audit firms (Tan, 2009; Lam, 2011; Tuan, 2014). As for meta-researches on factors affecting the audit quality in Vietnam, it is possible to mention researches by Thuy (2014), D. H. Hai and Trung (2015), Pham et al. (2017), Hai (2016), Hai (2017), Dung (2015). However, until now, there have been no researches in Vietnam, a developing country in Southeast Asia, affirming that audit organizational model consists of two main factors, namely the organizational structure and the operating mechanism, except for the $\mathrm{PhD}$ research by Hai (2014). Yet such research was mainly carried out according to the qualitative research method and was limited to the model establishment based on grounded theories and the expert survey method. The research has several limitations and should be expanded on the basis of carrying out experimental survey at audit firms in Vietnam. That is the authors' research perspective mentioned in this article.

The present article consists of the following contents:

1) Giving an overview of researches on factors affecting the organizational structure and operating mechanism of audit firms and relationship of the organizational structure with the operating mechanism (in this research, these two factors are collectively called the audit firm organizational model) affecting the audit quality.

2) Presenting the research model, research hypotheses and the following contents: research design, analyzing results of research on factors affecting the organizational structure and operating mechanism, and influence of the audit firm organizational model on the quality of audit services supplied by firms in the Vietnamese market.

3) Drawing conclusions and giving recommendations, pointing out shortcomings and orienting future research.

The article is divided into the following sections. Section 1 introduces basic characteristics of the Vietnamese audit market in the period 2010-2017. This section aims to help readers more clearly understand the independent audit situation of the past period in Vietnam. Section 2 deals with grounded theories to determine factors affecting the organizational structure, operating mechanism and audit quality. Then this section presents the theoretical research model and research hypotheses. Section 3 mentions data collection methods and research design. Section 4 is concerned with the results and analyzes the results of research on factors affecting the organizational structure, operating mechanism and audit quality in Vietnam through an experimental survey carried out in early 2018. End of the article mentions conclusions and recommendations, and points out shortcomings of the research as a foundation for carrying out new researches in the future.

\section{Background of study}

Vietnam has a long history of audit activities. However, before 1990, these activities were mainly carried out by the State through audit inspection. In 1986, Vietnam began its economic reform transformation from the centrally planned economy to the socialist-oriented market economy. After the promulgation of the Law on Foreign Investment, the presence of 
foreign investors in the country brought about a turning-point in the audit field. Independent audit started to take shape, which was marked with the establishment of Vietnam Auditing Company (VACO) in May 1991. Also in the same year, Ernst \& Young Ltd. was the first audit firm with $100 \%$ foreign capital permitted by the Vietnamese Government to establish an office and operate in Vietnam. Then many other Vietnamese audit firms were established. In addition, in the country, there are international audit firms, joint-venture auditing companies and companies with $100 \%$ domestic capital. There has been a rapid increase in the number of customers of audit firms, which has resulted in various types of audit firms such as state-owned enterprises, joint stock companies listed on stock exchanges, commercial banks.

By April 2018, the number of audit firms in Vietnam increased considerably: about 175 audit firms of various types: 02 companies with 100\% foreign capital (PwC, KPMG), 09 companies with foreign capital including 6 companies whose capital contribution members are organizations, and 164 companies with 100\% domestic capital (VACPA, 2017). An overview of the Vietnamese audit market in terms of company size is given in Table 1 below:

Table 1. Number of audit firms in Vietnam in the period 2010-2017 (source: Reports by VACPA (2010-2017); and authors' statistics)

\begin{tabular}{|l|c|c|c|c|c|c|c|c|}
\hline & 2010 & 2011 & 2012 & 2013 & 2014 & 2015 & 2016 & 2017 \\
\hline Total & 152 & 152 & 155 & 156 & 140 & 142 & 157 & 175 \\
\hline 1. According to capital owned \\
\hline $\begin{array}{l}\text { Companies with } \\
\text { 100\% foreign capital }\end{array}$ & 5 & 5 & 4 & 4 & 3 & 3 & 3 & 2 \\
\hline $\begin{array}{l}\text { Companies with } \\
\text { foreign capital }\end{array}$ & 3 & 3 & 5 & 5 & 8 & 7 & 8 & 9 \\
\hline $\begin{array}{l}\text { Companies with 100\% } \\
\text { domestic capital }\end{array}$ & 144 & 144 & 146 & 147 & 129 & 132 & 146 & 164 \\
\hline 2. As members of international audit firms \\
\hline Member firm & 10 & 11 & 11 & 14 & 12 & 15 & 19 & 23 \\
\hline Associate firm & 10 & 11 & 12 & 12 & 13 & 12 & 12 & 13 \\
\hline Correspondent firm & 3 & 1 & 1 & 1 & 1 & 1 & 1 & 1 \\
\hline None member & 129 & 129 & 131 & 127 & 114 & 114 & 125 & 138 \\
\hline
\end{tabular}

In the field of independent audit, workforce of audit firms is the core factor affecting the audit quality, brand name and prestige and contributing to improving the value and competitive capacity of the firms. In fact, in the period 2010-2017, there was a continuous increase in the number of professional employees and independent auditors at audit firms in Vietnam. This is shown in Table 2 below:

Table 2. Workforce of audit firms in Vietnam in the period 2010-2017 (source: Reports by VACPA (2010-2017); and authors' statistics)

\begin{tabular}{|l|c|c|c|c|c|c|c|c|}
\hline & 2010 & 2011 & 2012 & 2013 & 2014 & 2015 & 2016 & 2017 \\
\hline Professional employees & 7.439 & 8.223 & 8.715 & 9.148 & 9.543 & 9.705 & 9.920 & 10.615 \\
\hline Independent auditors & 1.247 & 1.415 & 1.554 & 1.400 & 1.528 & 1.709 & 1.975 & 2.083 \\
\hline Total & 8.686 & 9.638 & 10.269 & 10.548 & 11.071 & 11.414 & 11.895 & 12.698 \\
\hline
\end{tabular}


In short, over the past years, the Vietnamese independent audit market has developed to a certain extent in terms of the number of audit firms and workforce in the sector. This is also a basis for carrying out intensive researches on the audit quality, especially researches on factors affecting the audit quality in Vietnam such as the research by Dung (2015), P. T. Hai (2016).

\section{Literature review and theoretical research model}

\subsection{Theoretical basis}

\subsubsection{Size of audit firms}

DeAngelo (1981) carried out analysis of the impact of the audit size on the audit quality and concluded that the quality of audit services supplied large-size audit firms is often higher than that of audit services supplied by small-size audit firms (on the basis of market assessment). According to DeAngelo, the more customers audit firms attract the more economic pressure they are under. This compels them to maintain and improve the audit quality. Sharing the point of view with Dye (1993), Lennox (2005) and Zhan Shu (2000) believe that the audit quality has a relationship with financial resources of audit firms. Having strong financial resources (Deep-pocket), large-size audit firms are able to maintain the service quality at the high level, which minimizes the occurrence of legal suits.

Also, the research by C. C. Lee (2008) showed that the audit firm size has an obvious influence on the operation efficiency, especially in connection with comparison among international audit firms, large-size audit firms, and medium-size audit firms. Yet the research showed that such influence is insignificant in connection with comparison between mediumsize audit firms and small-size audit firms.

The Enron scandal in 2002 related to the audit firm Arthur Andersen shook the viewpoint that the audit quality is often better assured by large-size audit firms. However, up to now, most researches showed that the audit firm size is a factor that affects the audit quality. Normally, customers are willing to pay higher audit fees to invite auditors at large-size audit firms to carry out audit of financial statements with a view to enhancing customers' prestige.

The research by Zureigat (2011) in Jordan between two groups of companies including 198 companies unlisted and 262 companies listed on the Jordan stock exchange showed that the firm size and the ownership structure have an impact on the quality of audit services supplied by audit firms. And the research by Chen, Hsu, Huang, and Yang (2013) also shows that is a positive association between audit firms size and quality audit for the three categories of audit firms (national, regional, and local firms) in Taiwan from the 1992-2006.

The research by Amahalu and Beatrice (2017) showed that there is a positive and statistically significant relationship between audit firm size and audit quality. It was also empirically verified that audit firm size have a statistically significant relationship with audit quality of banks listed on the floor of Nigerian Stock Exchange at 5\% level of significance. And the research by Suseno and Nofianti (2018) showed that the reputation of public accounting firm was significantly affected by audit quality and audit quality was significantly affected by audit firm size in Indonesia. From the above analysis, the following hypothesis is proposed: 
$\mathrm{H}_{1 \mathrm{a}}$ : Audit firms size have a positive influence on the quality of audit services supplied by audit firms.

\subsubsection{Characteristics of auditors, professional staff}

For factors related to the characteristics of auditors and professional staff that affect the quality of audit, a lot of research has been mentioned. Including research on professional qualification, independence, work experience, auditor tenure.

According to Mautz (1961) the longer the term of office of an auditor is, the lower the audit quality is because it increases the auditor's dependence on the customer's board of directors. The auditor's familiarity towards the customer will result in doubts about the auditor's professional ability, which reduces the auditor's objectiveness. The research by Bonner and Lewis (1990) showed that, when an auditor/audit group is independent of a customer, the audit quality may be higher. The fact that an auditor/audit group assigned to carry out the audit has a thorough knowledge of the specialized field often has a significant impact on the audit quality.

The research by Ghosh and Moon (2005) provided insight into the recent debate surrounding auditor tenure, independence, and audit quality by analyzing the relationship between auditor tenure and audit quality as perceived by capital market participants. Sharing the point of view with Rahmina and Agoes (2014) believe that the auditor tenure has a relationship with audit quality.

The research by Aldhizer III, Miller, and Moraglio (1995), Chen, Kelly, and Salterio (2012) showed that auditors' experience has an influence on the audit quality through the assessment of risks and the proper design of audit plans. According to a study by Chen, Dai, Kong, and Tan (2017), the international work experience of individual auditors affects the quality of auditing in the Chinese market. The research by Bonner and Lewis (1990) also showed that the experience factor is as important as an auditor's intensiveness and has an impact on the audit quality. When an experienced auditor carries out audit for customers, users of audit results will feel satisfied with the quality of audit services.

In Vietnam, through research by Thuy (2014), Dung (2015) factors related to independence, term of auditors, work experience and professional qualification of auditors, professional staff have an impact on the audit quality. According to Tran et al. (2018) showed that the model have eight factors that affect the quality of the audit, those are the attitude of auditors, independence, industry expertise, qualifications of auditors, experience, time audit, quality control procedures, and process of auditing. The research by Hai and Trung (2015) also showed that occupational qualification is an important factor affecting the audit quality in the establishment of the business financial statements. Sharing the point of view with Anh and Tam (2019) believe that the audit quality has a relationship with auditor's quality.

From the above analysis, the following hypothesis is proposed:

$\mathrm{H}_{1 \mathrm{~b}}$ : Characteristics of auditors, professional staff have a positive influence on the quality of audit services supplied by audit firms. 


\subsubsection{Legal system}

The research by DeFond and Zhang (2014) suggests that the legal environment plays a prominent role in shaping the quality of audit, the recent establishment of regulations and auditing standards especially the promulgation of Sarbanes-Oxley Act 2002 in the United States, along with some provisions in a few countries, has had an impact on audit quality and contributes to improving audit quality. New regulations and interventions by the Audit Commission have increased the need for audit quality of clients, encouraged the improvement of supervision. In contrast, there is very little evidence against the ban on non-audit services adversely affecting audit quality. In fact, certain types of evidence show that non-audit services improve audit quality. Gao and Zang (2017) identify the conditions under which stricter auditing standards increase or decrease audit quality in our research.

The study of Hai (2016) also indicates that the legal system is one of the factors that influence the audit quality in the Vietnamese market. Previously, studies by Thuy (2014), Dung (2015) have come to the conclusion that the legal system has an impact on audit quality in Vietnam. From the above analysis, the following hypothesis is given:

$\mathrm{H}_{1 \mathrm{c}}$ : The legal system has a positive impact on the audit quality of audit firms

\subsubsection{Internal and external quality control of audit firms}

In Vietnam, reports of annual audit quality control by the Vietnam Association of Certified Public Accountants (VACPA) indicate that the higher audit firms' rate of checked errors is, the lower audit quality is. It also demonstrates that internal quality control is not reliable. Some previous published studies such as Tan (2009) suggested that most small audit firms in Vietnam cannot regularly maintain or implement the effective establishment of policy system and quality control procedures due to the lack of resources, the quality control from the internal independent audit firms in Vietnam has not been properly addressed.

In addition, through her research, the author $(\mathrm{Ha}, 2012)$ focused on assessing the real state of financial statements and audit quality control by public interest units in Vietnam in the period of 2008-2010. The results show that the relationship between external quality control and audit quality is extremely necessary and important, especially the audit of financial statements by listed enterprises, mass companies in Vietnam. The other studies by Tan (2009), Tuan (2014) have also suggested that internal audit quality control plays an extremely important role in the quality of audit reports and providing information to different subjects for use. From the above analysis, the following hypothesis is given:

$\mathrm{H}_{1 \mathrm{~d}}$ : Internal and external quality control of the audit firms has a positive impact on the audit quality

\subsubsection{Corporate governance mechanism of audit firms}

Up to now, many published studies have shown that there is a correlation between corporate governance and audit quality. The positive association between high audit quality and high quality governance structures have been approved by most studies. The research by Seyed (2014) showed that corporate governance had an impact on the quality of the audit. Corporate governance mechanisms are measured by board size, CEO duality, independent direc- 
tors, audit committee, while audit quality are measured by audit fee and auditor reputation. The other study by Gacar (2016) have also suggested that the relationship between corporate governance and audit quality in the publicly listed companies.

The research by Aladdin, Zeena, and Islam (2018) in Palestine including 46 firms listed on the Palestine stock exchange (PSE) for the period from 2013 to 2015 showed that was a positive association between corporate governance and auditor quality choice. The companies with a high ownership concentration, larger board size and the existence of audit committee tend to hire a high quality auditor.

There are also studies that suggest that there is no consistent relationship between good corporate governance mechanisms and audit quality (Kasim, Hashim, \& Salman, 2016; Hoseinbeglou, Masrori, \& Asadzadeh, 2013).

Empirical tests on the relationship between the corporate governance mechanisms and audit quality are mixed. Some of the findings have a relationship while some are not. This may be due to the many ways to measure audit quality which might be influenced by the statutory background, the operational function of the companies, and culture. From the above analysis, the author goes between the governance mechanism and the quality of the audit is related, the following hypothesis is given:

$\mathrm{H}_{1 \mathrm{e}}$ : Coporate governance mechanism of audit firms has a positive impact on the audit quality

\subsubsection{The relationship between size, staff and auditors to the organizational structure}

According to Hai (2014), the size of audit firms, staff, and auditors in terms of both quantity and quality affect the organization of management, operation and arrangement of resources of audit firms to achieve the set targets. From the above analysis, the following hypothesis is given:

$\mathrm{H}_{2 \mathrm{a}}$ : The size of auditing enterprises has a positive impact on organizational structure of audit firms

$\mathrm{H}_{2 \mathrm{~b}}$ : Staff and auditors has a positive impact on organizational structure of audit firms

2.1.7. The relationship between the legal system, the quality control, the corporate governance to the operating mechanism of audit firms

According to Phan Thanh Hai (2014), whether an audit firm operates effectively or not, the operating mechanism demonstrates the flexibility and affect the quality and efficiency of operations. Flexibility in the operation of the audit firms is reflected in the corporate governance mechanism of enterprises, the design and operation of quality control and is subject to the constraints of the legal system, regulation of business lines and audit firms. From the above analysis, the following hypothesis is given:

$\mathrm{H}_{3 \mathrm{a}}$ : Legal system has a positive impact on the operating mechanism of audit firms

$\mathrm{H}_{3 \mathrm{~b}}$ : Quality control has a positive impact on the operating mechanism of audit firms

$\mathrm{H}_{3 \mathrm{c}}$ : Corporate governance mechanism has a positive impact on the operating mechanism of audit firms 


\subsubsection{The relationship between the organizational model of auditing activities (organizational structure and operation mechanism) and audit quality}

The study by Duc (2002) believe that in terms of the relationship between the regulatory organization and the professional supervision of the audit firms, the auditing structure can be divided into four models: (1) self-control model mostly through the role of professional organization (model of United States before 2002 without Sarbanes-Oxley Act); (2) statutory model mostly through the role of the state (model of France); (3) independent board model through the role of a multi-component committee (model of British ); (4) State model - Advisory Council (model of Japan).

The research work of the DG Internal Market (2007) on the relevant regulations and the existence of agencies for audit control and the promulgation of statutes, standards and auditing standards in European countries. The results of the research are published on the basis of consideration of the establishment and development of organizations responsible for the promulgation of standards, regulations, norms, rules and instruction for audit as well as the organizations responsible for supervising auditing professions, the practice of auditors in European countries including Austria, Belgium, Czech Republic, Denmark, France, Germany, Greece, Hungary, Italy, Luxembourg, Netherlands, Poland, Portugal, Ireland, Spain, Sweden, England and Cyprus. The researchers concludes that the establishment and organization of the agencies involved in the promulgation and supervision of auditing professions in the various countries of the European Union depending on the characteristics of the political and social mechanisms and the starting point of audit formation in that country. The structure and mode of operation of these organizations play a very important role in ensuring the quality of the auditing profession in each country.

In Vietnam, Hai's research (2014) in his doctoral dissertation also states: "Organizational model of auditing activities is a term that expresses characteristics related to operating structure and mechanics of auditing activities". The organizational structure reflects the hardware of audit firms, the operating mechanism represents the software, the flexible part of audit firms in the process of providing services to customers. Factors such as size of audit firms, staff and auditors have a positive impact on the organizational structure of audit firms. At the same time, the elements of the legal system, internal and external quality control, and corporate governance mechanism have a positive impact on the operating mechanism of audit firms. Also, the organizational structure and operating mechanism are two important factors that affect the quality of auditing services and audit firms supplied to the market. From the above analysis, the following hypothesis is given:

$\mathrm{H}_{4}$ : The organizational structure of audit firms has a positive impact on audit quality

$\mathrm{H}_{5}$ : The operating mechanism of audit firms has a positive impact on audit quality

In conclusion, from the above research reviews, depending on the views and perspectives of the authors, the factors influencing audit quality are quite varied because the audit quality is an invisible product interested by many people. However, none of the authors proposed a general research of model elements including organizational structure and operating mechanism while considering their impacts on audit quality. Therefore, this is also a strong theoretical basis for the author to determine the main factors related to the organizational model of auditing activities and to conduct their researches. 


\subsection{Theoretical research model}

As mentioned in the previous section, synthesizing from many previous published researches, the author presents the model used for the researches as follows (Figure 1):

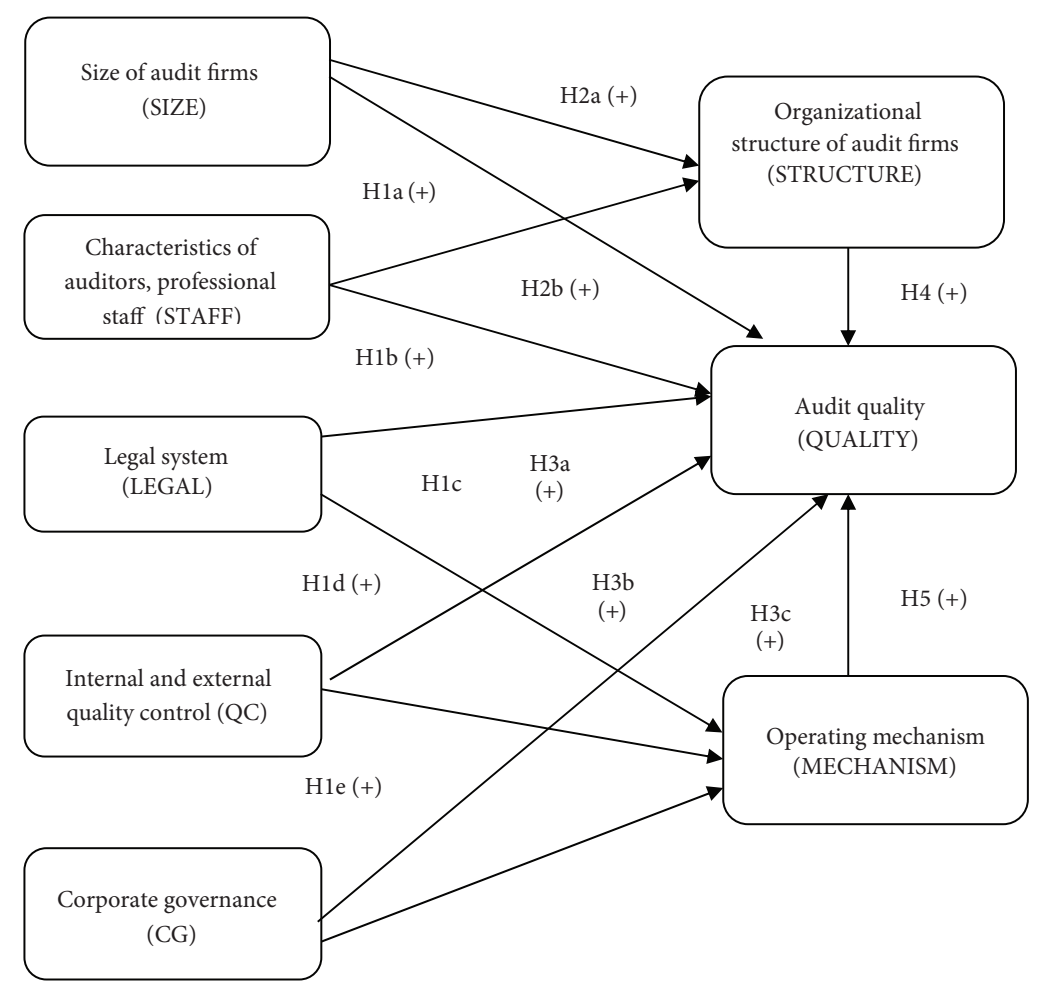

Figure 1. Model and hypotheses (source: authors based on literature review, 2018)

\section{Data and research methodology}

\subsection{Data collection}

To test hypotheses, the research team collected data from interviews with auditors working in audit firms in Vietnam. The data collection was done by directly handing out the questionnaires and responding by filling in the independent questionnaire. The results were analyzed by SPSS software, the scales are tested to determine reliability. The model was then established to test the hypotheses.

\subsection{Scale}

The research designed the questionnaires with 37 observations including three dependent variable, using a 5-level Likert scale (Score 1: Absolutely disagree, Score 5: Totally agree). Questionnaires and scales were checked and corrected based on 4 bases: (1) Qualitative research, (2) Expert interviews (10 people), (3) In-depth interviews with 10 auditors, (4) Trial results of 30 samples. 
The scale of Size of Audit firms (Sign: SIZE) includes 5 observations. The scale of Characteristics of auditors, professional staff (Sign: STAFF) includes 5 observations. The scale of Legal System (Sign: LEGAL) includes 5 observations. The scale of Quality control (Sign: QC) includes 4 observations. The scale of Corporate governance (Sign: CG) includes 4 observations. These scales are inherited from the original researches by (Dung, 2015; Hai, 2016; Pham, Amaria, Bui, \& Tran, 2014; Hai, 2014; Thuy, 2014).

The scale of Operating mechanism (Sign: MECHANISM) includes 4 observations. The scale of Organizational structure of audit firms (Sign: STRUCTURE includes 6 observations. The scale of Audit quality (Sign: QUALITY) includes 5 observations. These scales are inherited and corrected from the researches by (Dung, 2015; Hai, 2016; Hai, 2014; Thuy, 2014).

\subsection{Sample size}

As presented in section 2 of the operation of the independent audit in Vietnam by the beginning of 2018, there were 2.083 auditors. The author sent the survey questionnaire to 300 auditors in this list and collected 275 responses from January 2018 to April 2018. Sample selection is conducted randomly based on the detailed information provided by the VACPA to send emails or request an appointment for a live interview. As a result, after rejecting invalid answers, 270 questionnaires were processed. Compared with the initial calculation, the questionnaire with 37 observations needed at least $37 \times 5=185$ samples, thus the number of processed questionnaires are acceptable. According to Bollen (1989), the appropriate ratio for choosing the sample size with the number of parameters in the metric analysis should be $5: 1$.

\subsection{Analytical methods}

The authors tested the model using SPSS 20 software in combination with AMOS 20 with the following steps:

- To verify the scale: The scales were verified in turn by three techniques: Cronbach's Alpha Reliability Coefficient, Exploratory Factor Analysis (EFA) and Confirmatory Factor Analysis (CFA).

- To verify the model: The proposed theoretical research model and research hypotheses were verified by linear Structural Equation Modeling (SEM) with AMOS software 20.

\section{Results and discussion}

Based on the results surveyed from 270 auditors as described above, the author analyzes the impact of each factor based on the original theoretical model. This result is presented as follows:

\subsection{Descriptive statistics about the samples}

SPSS 20 software was used to conduct the analysis in the research. Of the 270 auditors, the information of samples (270 people) was shown in Table 3. 
Table 3. Descriptive statistics about the samples (source: authors' survey, 2018)

\begin{tabular}{|l|c|c|}
\hline \multicolumn{1}{|c|}{ Characteristics } & Frequency & Percentage \\
\hline Gender & $\mathrm{N}=270$ & 100 \\
\hline Male & 115 & 42.6 \\
\hline Female & 155 & 57.4 \\
\hline Working experience & $\mathrm{N}=270$ & 100 \\
\hline Under 5 years & 70 & 25.9 \\
\hline From 5 to 10 years & 116 & 43 \\
\hline From 10 to under 15 years & 45 & 16.7 \\
\hline From 15 to under 20 years & 20 & 7.4 \\
\hline Over 20 years & 19 & 7.0 \\
\hline Age of auditors & $\mathrm{N}=270$ & 100 \\
\hline From 23 to under 30 years & 138 & 51.1 \\
\hline From 31 to under 40 years & 81 & 30.0 \\
\hline From 41 to under 50 years & 24 & 8.9 \\
\hline From 51 to under 60 years & 14 & 5.2 \\
\hline Over 60 years & 13 & 4.8 \\
\hline
\end{tabular}

Based on Table 3, the auditors who participated in the survey were younger (less than 40 years old, $81.1 \%$ ), the experience of auditing firms was less than 10 years (68.9\%). By gender, $57.4 \%$ of the respondents were female auditors.

\subsection{Testing of Cronbach's alpha coefficient}

Table 4. Results of testing of Cronbach's Alpha coefficient of scales (source: authors'survey, 2018)

\begin{tabular}{|c|c|c|c|c|c|}
\hline No & Scale & Symbol & $\begin{array}{l}\text { Number } \\
\text { of obs. } \\
\text { variables }\end{array}$ & $\begin{array}{l}\text { Cronbach's } \\
\text { Alpha }\end{array}$ & Remarks \\
\hline & \multicolumn{5}{|l|}{ Independent variables } \\
\hline 1 & Legal system & LEGAL & 5 & 0.907 & \\
\hline 2 & $\begin{array}{l}\text { Characteristics of au- } \\
\text { ditors, professional staff }\end{array}$ & STAFF & 4 & 0.897 & \\
\hline 3 & Corporate Governance & CG & 4 & 0.856 & \\
\hline 4 & Quality control & QC & 4 & 0.902 & \\
\hline \multirow[t]{2}{*}{5} & Size of audit firms & SIZE & 5 & 0.895 & \\
\hline & \multicolumn{5}{|l|}{ Dependent variables } \\
\hline 1 & $\begin{array}{l}\text { Organizational } \\
\text { structure }\end{array}$ & $\begin{array}{l}\text { STRUC- } \\
\text { TURE }\end{array}$ & 5 & 0.898 & $\begin{array}{l}\text { STRUCTURE4 variable was } \\
\text { rejected due to Corrected } \\
\text { Item }- \text { Total Correlation }= \\
0.245<0.3 \text {. }\end{array}$ \\
\hline 2 & Operating mechanism & $\begin{array}{l}\text { MECHA- } \\
\text { NISM }\end{array}$ & 4 & 0.831 & \\
\hline 3 & Audit quality & QUALITY & 5 & 0.942 & \\
\hline
\end{tabular}


Results of testing of Cronbach's Alpha for the scales described in Table 4 above showed that these scales had the Cronbach's Alpha coefficient of $>0.6$ and the Corrected Item - Total Correlation of $>0.3$. Thus, from the first 37 observations including eliminated STRUCTURE4 notation, the model used in the next EFA analysis includes 36 observations.

\subsection{Exploratory factor analysis (EFA) and confirmatory factor analysis (CFA)}

\subsubsection{Exploratory factor analysis (EFA) of scales}

From the results of the survey, the data was analyzed using exploratory factor analysis with the support of SPSS 16 software, the final results of exploratory factor analysis are presented in Table 5.

Table 5. Results of testing of EFA of scales (source: authors' survey, 2018)

\begin{tabular}{|c|l|l|c|c|c|c|}
\hline No & \multicolumn{1}{|c|}{ Scales } & \multicolumn{1}{|c|}{ Symbol } & KMO & Sig & $\begin{array}{c}\text { Cumulative } \\
\text { of Variance }\end{array}$ & $\begin{array}{c}\text { Eigen } \\
\text { Value }\end{array}$ \\
\hline 1 & Legal system & LEGAL & 0.891 & .000 & 0.72971 & 3.649 \\
\hline 2 & Size of audit firms & SIZE & 0.815 & .000 & 0.70842 & 3.542 \\
\hline 3 & $\begin{array}{l}\text { Characteristics of au- } \\
\text { ditors, professional staff }\end{array}$ & STAFF & 0.711 & .000 & 0.76591 & 3.064 \\
\hline 4 & Corporate Governance & CG & 0.773 & .000 & 0.70538 & 2.822 \\
\hline 5 & Quality control & QC & 0.833 & .000 & 0.77579 & 3.103 \\
\hline 6 & Organizational structure & STRUCTURE & 0.793 & .000 & 0.71746 & 3.588 \\
\hline 7 & Operating mechanism & MECHANISM & 0.803 & .000 & 0.66579 & 2.663 \\
\hline 8 & Audit quality & QUALITY & 0.902 & .000 & 0.81439 & 4.072 \\
\hline
\end{tabular}

The analysis results above showed that the coefficient of KMO was $>0.5$, the Batlett checking had a p-value of $0.000<0.05$, a cumulative of variance was $>50 \%$, the factor loadings were greater than 0.5 and the Eigen Value was $>1$. Thus the criteria for using the EFA showed that the factors were consistent with the data set of the research.

\subsubsection{Results of confirmatory factor analysis (CFA)}

The suitability of the model

The model has 559 degrees of freedom, CFA (Figure 2) showed that $\mathrm{p}=.000$; The GFI value $=0.879, \mathrm{RMSEA}=0.031$ which were small; Chi-Square $/ \mathrm{df}=1.265$ (less than 2$) ; \mathrm{TFI}=$ 0.977 , CFI $=0.979$ which were greater than 0.9 , AGFI $=0.856>0.8$. Thus the analysis results showed that the data was acceptable with the proposed model.

According to Table 6, it can be seen that the CRs were greater than 0.7, the total cumulative of variance was greater than $50 \%$, so it can be concluded that the components of the scale of functional quality were reliable and convergent. Performing the analysis of the correlation coefficient between the factor pairs, it found that the highest value was 0.585 , was relatively small and did not exceed 0.85 , so the factors satisfied the discriminant validity. 
Table 6. Results of tests for composite reliability and variance extracted of scales (source: authors' survey, 2018)

\begin{tabular}{|l|l|c|c|c|}
\hline \multicolumn{1}{|c|}{ Scales } & \multicolumn{1}{|c|}{ Symbol } & $\begin{array}{c}\text { Number of obs. } \\
\text { variables }\end{array}$ & $\begin{array}{c}\text { Composite } \\
\text { reliability }\end{array}$ & $\begin{array}{c}\text { Variance } \\
\text { extracted }\end{array}$ \\
\hline 1. Legal system & LEGAL & 5 & 0.907 & 0.72971 \\
\hline 2. Size of audit firms & SIZE & 5 & 0.895 & 0.70842 \\
\hline $\begin{array}{l}\text { 3. Characteristics of } \\
\text { auditors, professional } \\
\text { staff }\end{array}$ & STAFF & 4 & 0.897 & 0.76591 \\
\hline 4. Quality control & QC & 4 & 0.902 & 0.77597 \\
\hline 5. Corporate Governance & CG & 4 & 0.856 & 0.70538 \\
\hline $\begin{array}{l}\text { 6. Organizational } \\
\text { structure }\end{array}$ & STRUCTURE & 5 & 0.898 & 0.71764 \\
\hline 7. Operating mechanism & MECHANISM & 4 & 0.831 & 0.66579 \\
\hline 8. Audit quality & QUALITY & 5 & 0.942 & 0.81439 \\
\hline
\end{tabular}

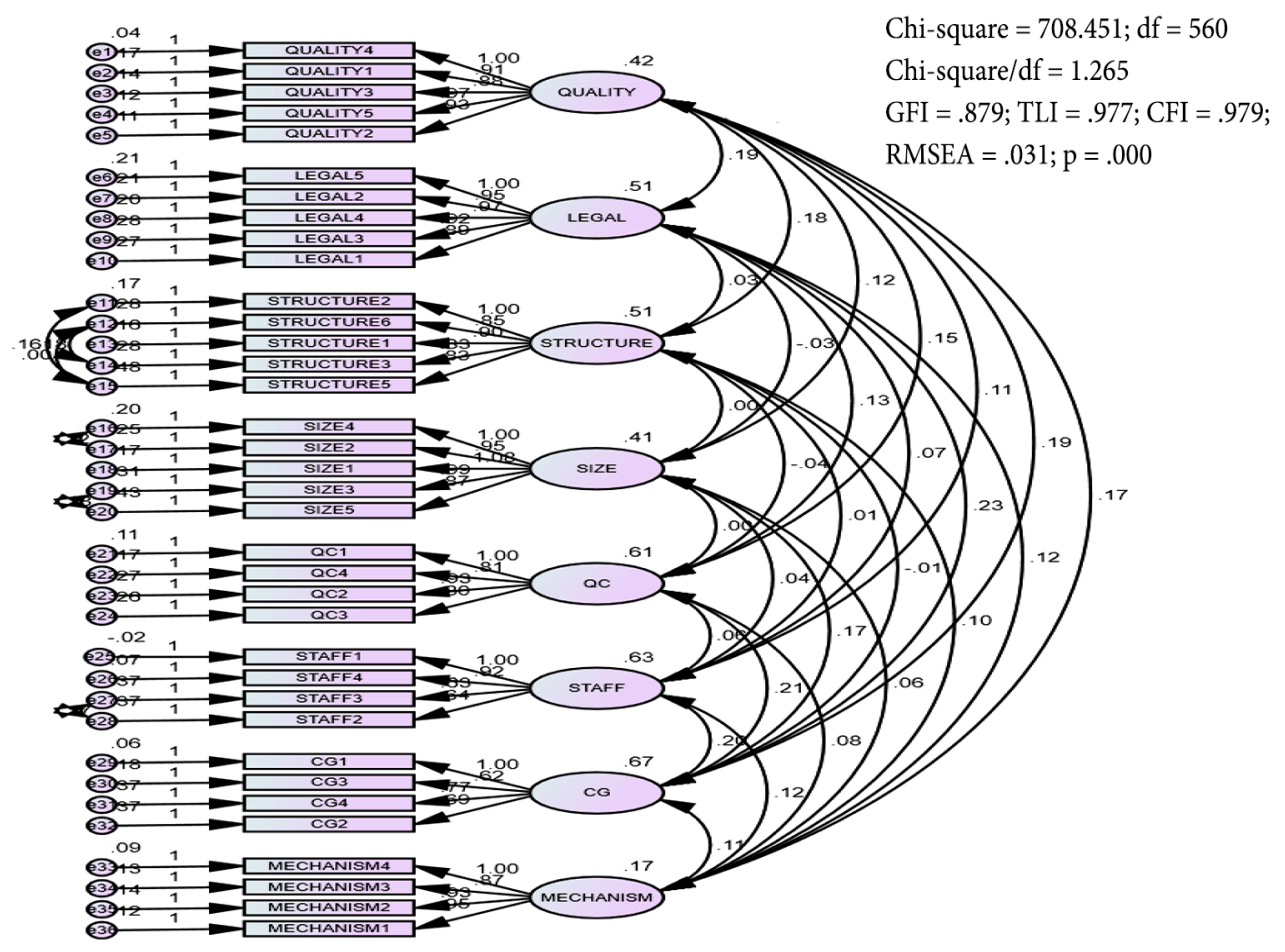

Notes: Chi-square/df. Ratio < 5 (Schumacker \& Lomax, 2004), TLI > 0.90 (Hair, Black, Babin, \& Anderson, 2006), CFI > 0.95 (Hu \& Bentler, 1999), RMSEA < 0.07 (Hair et al., 2006), p-value < 0.05 (Hair et al., 2006).

Figure 2. Results of standardized CFA (source: authors' survey, 2018) 


\subsection{Testing of model and research hypotheses}

\subsubsection{Testing of model}

The author uses SEM to test existing models and research hypotheses. The results of the research model estimation showed that the test model had 450 degrees of freedom $(p=0.00)$ and the indicators indicated that the model was appropriate for market data (chi-square/ $\mathrm{df}=$ 1.536; GFI $=0.870$; CFI $=0.960$; $\mathrm{TLI}=0.956$; and $\mathrm{RMSEA}=0.045$ ).

The results of the primary parameter estimation showed that organizational structure and operational mechanism have an impact on quality of audit and were statistically significant $(\mathrm{p}<5 \%)$. Thus, the relation of concepts has reached the theoretical expectation (Table 7).

Table 7. Results of test for discriminant validity of research concepts (source: authors' survey, 2018)

\begin{tabular}{|l|c|l|c|c|c|c|}
\hline \multicolumn{2}{|c|}{ Relationship } & Estimate & S.E. & C.R. & P \\
\hline STRUCTURE & $<---$ & SIZE & -.011 & .077 & -.143 & .886 \\
\hline STRUCTURE & $<---$ & STAFF & .006 & .056 & .102 & .919 \\
\hline MECHANISM & $<---$ & LEGAL & .176 & .038 & 4.564 & $* * *$ \\
\hline MECHANISM & $<---$ & QC & .075 & .033 & 2.246 & .025 \\
\hline MECHANISM & $<---$ & CG & .088 & .032 & 2.735 & .006 \\
\hline QUALITY & $<---$ & LEGAL & .172 & .047 & 3.691 & $* * *$ \\
\hline QUALITY & $<---$ & SIZE & .200 & .049 & 4.096 & $* * *$ \\
\hline QUALITY & $<---$ & STAFF & .013 & .035 & .382 & .702 \\
\hline QUALITY & $<---$ & QC & .124 & .039 & 3.164 & .002 \\
\hline QUALITY & $<---$ & CG & .059 & .038 & 1.561 & .119 \\
\hline QUALITY & $<---$ & STRUCTURE & .260 & .044 & 5.859 & $* * *$ \\
\hline QUALITY & $<---$ & MECHANISM & .593 & .093 & 6.373 & $* * *$ \\
\hline
\end{tabular}

Estimation parameters (standardized) were statistically significant $(\mathrm{p}<5 \%)$. Based on the regression weights, it can be seen that:

- Legal system (LEGAL), Quality control (QC), Corporate Governance (CG) of audit firm have the same impacts on the Operating mechanism (MECHANISM) of audit firm. In these 3 factors, the factor of legal system is the most influential, followed by Corporate Governance and Quality control.

- Factors as Legal system (LEGAL), Size of audit firms (SIZE) of audit firm, Quality control (QC), Organizational structure (STRUCTURE) of audit firm and Operating mechanism (MECHANISM) of audit firm have the same impacts on the audit quality. Of which the Operating mechanism itself and Organizational structure are the most influential (Table 8). 
Table 8. Testing parameters in the research model (standardized) (source: authors' survey, 2018)

\begin{tabular}{|l|c|l|c|}
\hline \multicolumn{3}{|c|}{ Relationship } & Estimate \\
\hline MECHANISM & $<---$ & LEGAL & .309 \\
\hline MECHANISM & $<---$ & QC & .145 \\
\hline MECHANISM & $<---$ & CG & .189 \\
\hline QUALITY & $<---$ & LEGAL & .224 \\
\hline QUALITY & $<---$ & SIZE & .238 \\
\hline QUALITY & $<---$ & QC & .179 \\
\hline QUALITY & $<---$ & STRUCTURE & .303 \\
\hline QUALITY & $<---$ & MECHANISM & .413 \\
\hline
\end{tabular}

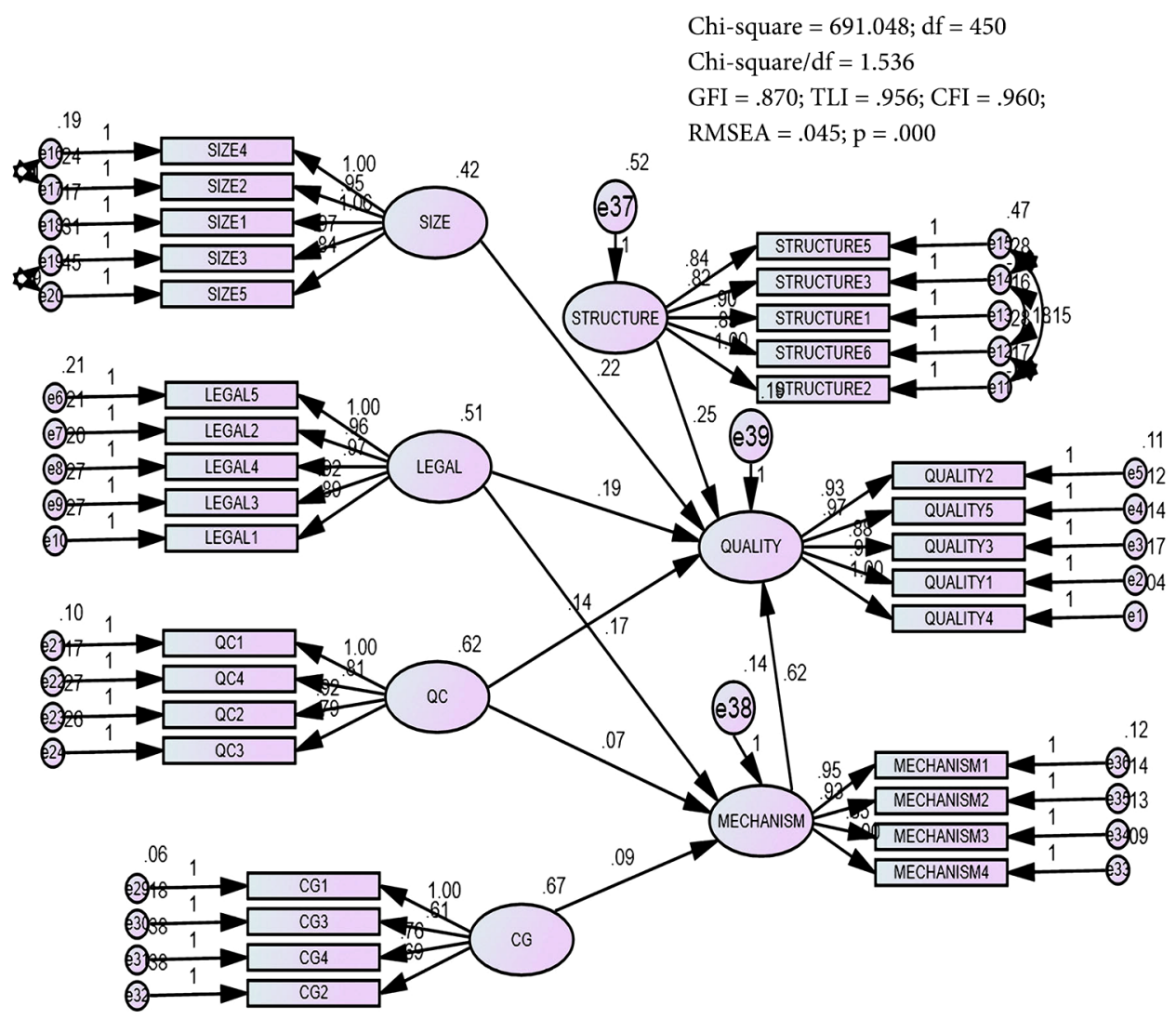

Notes: Chi-square/df. Ratio < 5 (Schumacker \& Lomax, 2004), TLI > 0.90 (Hair et al., 2006), CFI > 0.95 (Hu \& Bentler, 1999), RMSEA < 0.07 (Hair et al., 2006), p-value < 0.05 (Hair et al., 2006).

Figure 3. Results of the model testing (standardized) (source: authors' survey, 2018) 


\subsubsection{Testing of research hypothesis}

Table 9. Results of hypotheses testing (source: authors' survey, 2018)

\begin{tabular}{|l|l|l|c|c|c|c|c|}
\hline \multicolumn{2}{|c|}{ Relationship } & Estimate & S.E. & C.R. & P & Label \\
\hline STRUCTURE & $<---$ & SIZE & -.011 & .077 & -.143 & .886 & H2a Rejected \\
\hline STRUCTURE & $<---$ & STAFF & .006 & .056 & .102 & .919 & H2b Rejected \\
\hline MECHANISM & $<---$ & LEGAL & .176 & .038 & 4.564 & $* * *$ & H3a Accepted \\
\hline MECHANISM & $<---$ & QC & .075 & .033 & 2.246 & .025 & H3b Accepted \\
\hline MECHANISM & $<---$ & CG & .088 & .032 & 2.735 & .006 & H3c Accepted \\
\hline QUALITY & $<---$ & LEGAL & .172 & .047 & 3.691 & ${ }^{* * *}$ & H1c Accepted \\
\hline QUALITY & $<---$ & SIZE & .200 & .049 & 4.096 & ${ }^{* * *}$ & H1a Accepted \\
\hline QUALITY & $<---$ & STAFF & .013 & .035 & .382 & .702 & H1b Rejected \\
\hline QUALITY & $<---$ & QC & .124 & .039 & 3.164 & .002 & H1d Accepted \\
\hline QUALITY & $<---$ & CG & .059 & .038 & 1.561 & .119 & H1e Rejected \\
\hline QUALITY & $<---$ & STRUCTURE & .260 & .044 & 5.859 & ${ }^{* * *}$ & H4 Accepted \\
\hline QUALITY & $<---$ & MECHANISM & .593 & .093 & 6.373 & $* * *$ & H5 Accepted \\
\hline
\end{tabular}

Thus, the research results (Table 9, Figure 3) showed that the factors that affect the operating mechanism are: legal system, quality control, corporate governance. Factors that affect the audit quality include: legal system, quality control, size of audit firm, organizational structure and operating mechanism of audit firm. Of which the organizational structure and operating mechanism are the two factors that have the greatest impact on the audit quality.

\section{Conclusions}

The findings of the research revealed that the factors having the same impact on operating mechanism of the audit firm were the legal system, quality control and the corporate governance; factors that affect the audit quality included: legal system, quality control, size of the audit firm, organizational structure and operating mechanism of the audit firm. Of which the operating mechanism had the greatest impact, followed by organizational structure. This research also showed that factors such as size of the audit firm and staff were not factors that had a decisive impact on the organizational structure of the audit firm. At the same time, corporate governance has no relation to the operational mechanism and quality of audit. This result of the study in Vietnam is similar to that of Kasim, Hashim, and Salman (2016), Hoseinbeglou, Masrori, and Asadzadeh (2013) published earlier.

Thus, through the results of this research, in order to increase the audit quality in the Vietnamese market, managers at the state level and audit firms should pay attention to improving issues related to the legal system, quality control, corporate governance, size of the audit firm, organizational structure and operating mechanism of the firm. State management agencies in Vietnam should continue reviewing and improving the legal system for independent audit. 
The results of the above research also clarified the positive relationship between the size and the audit quality of a firm. So in the coming time, audit firms need to be proactive in increasing capital, joining international audit companies, and improving their competitive capacities in order to increase the quality of their services provided to the market.

The audit quality is closely related to the operating mechanism of the audit firm, which was shown in the research results that is the most influential factor to the audit quality. Therefore, the audit firms themselves need to pay attention to continuous improvement of internal corporate governance, quality control and maintenance of a stable and rational organizational structure.

The current study has certain limitations for instance, this research was carried out using a convenience sampling method, leading that the results were mainly subjective by the research author, which reduced the objectivity and generalization. Therefore, the further researches should consider the use of probability sampling method to ensure higher representation and increase the size of the research sample for more accurate and more general analysis results. Secondly, the research scope has only been conducted in the Vietnamese market recently, so the results of the empirical research only provided some short term conclusions and recommendations. The further researches can expand the scope of the survey in both space and time for a more complete and comprehensive assessments.

\section{References}

Al-Ajmi, J. (2009). Audit firm, corporate governance, and audit quality: Evidence from Bahrain. Advances in Accounting, 25(1), 64-74. https://doi.org/10.1016/j.adiac.2009.02.005

Aldhizer III, G. R., Miller, J. R., \& Moraglio, J. F. (1995). Common attributes of quality audits. Journal of Accountancy, 179(1), 61. Retrieved from https://search.proquest.com/openview/3369c7c4350d5 $506770 \mathrm{~cd} 2 \mathrm{~b} 4 \mathrm{ee} 543523 / 1$ ? pqorigsite $=$ gscholar $\& \mathrm{cbl}=41065$

Aladdin, D., Zeena, M., \& Islam, A. (2018). Corporate governance and auditor quality choice: Evidence from Palestinian corporations. International Journal of Economics and Financial Issues, 8(2), 47-53. Retrieved from http://www.econjournals.com/index.php/ijefi/article/view/6071

Amahalu, N. N., \& Beatrice, O. E. (2017). Determinants of audit quality: Evidence from deposit money banks listed on Nigeria stock exchange. International Journal of Academic Research in Accounting, Finance and Management Sciences, 7(2), 117-130. https://doi.org/10.6007/IJARAFMS/v7-i2/2877

Gacar, A. (2016). Relationship between AuditQuality and corporate governance: An empirical research in Borsa Istanbul. IOSR Journal of Business and Management, 18(11), 84-88. Retrieved from http:// www.iosrjournals.org/iosr-jbm/papers/Vol18-issue11/Version-6/K1811068488.pdf

Anh, N. T. M., \& Tam, N.T. (2019). Auditing financial statements in insurance enterprises: The case of Vietnam. Management Science Letters, 9(2019), 313-324. Retrieved from http://www.growingscience.com/msl/Vol9/msl_2019_21.pdf

Bollen, K. A. (1989). A New Incremental Fit Index for general structural equation models. Sociological Methods \& Research, 17(3), 303-316. https://doi.org/10.1177/0049124189017003004

Bonner, S., \& Lewis, B. (1990). Determinants of auditor expertise. Journal of Accounting Research, 28, 1-20. https://doi.org/10.2307/2491243

Chadegani Aghaei, A. (2011). Review of studies on audit quality. International Conference on Humanities, Society and Culture, 20, 312-317. https://doi.org/10.2139/ssrn.2227359 
Chen, Q., Kelly, K., \& Salterio, S. E. (2012). Do changes in audit actions and attitudes consistent with increased auditor scepticism deter aggressive earnings management? An experimental investigation. Accounting, Organizations and Society, 37(2), 95-115. https://doi.org/10.1016/j.aos.2011.11.001

Chen, X., Dai, Y., Kong, D., \& Tan, W. (2017). Effect of international working experience of individual auditors on audit quality: Evidence from China. Journal of Business Finance and Accounting, 44(78), 1073-1108. https://doi.org/10.1111/jbfa.12257

Chen, Y.-S., Hsu, J., Huang, M.-T., \& Yang, P.-S. (2013). Quality, size, and performance of audit firms. The International Journal of Business \& Finance Research, 7(5), 89-105. Retrieved from https:// papers.ssrn.com/sol3/papers.cfm?abstract_id=2262503

DeAngelo, L. (1981). Auditor independence, "low-balling", and disclosure regulation. Journal of Accounting and Economics, 3(2), 113-127. https://doi.org/10.1016/0165-4101(81)90009-4

DeFond, M., \& Zhang, J. (2014). A review of archival auditing research. Journal of Accounting and Economics, 58(2-3), 275-326. http://doi.org/10.1016/j.jacceco.2014.09.002

DG Internal Market. (2007). Ownership rules of audit firms and their consequences for audit market concentration. Prepared for DG Internal Market Services. Retrieved from http://ec.europa.eu/internal_market/auditing/docs/market/oxera_report_en.pdf

Duc, V. H. (2002). Establishing the system of auditing standards in Vietnam (PhD Thesis). University of Economics Ho Chi Minh City, Vietnam (in Vietnamese).

Dung, P. Van. (2015). The factors affecting audit quality of audit firms in Vietnam oriented to strengthen competitive capability in international integration conditions (PhD Thesis). University of Economics Ho Chi Minh City, Vietnam (in Vietnamese).

Dye, R. A. (1993). Auditing standards, legal liability, and auditor wealth. Journal of Political Economy, 5, 887-914. https://doi.org/10.1086/261908

Favere-Marchesi, M. (2000). Audit quality in ASEAN. The International Journal of Accounting 35(1), 121-149. https://doi.org/10.1016/S0020-7063(99)00049-7

Francis, J. R. (2011). A framework for understanding and researching audit quality. Auditing: A Journal of Practice \& Theory, 30(2), 125-152. https://doi.org/10.2308/ajpt-50006

Ghosh, A., \& Moon, D. (2005). Auditor tenure and perceptions of audit quality. Accounting Review, 80(2), 585-612. https://doi.org/10.2308/accr.2005.80.2.585

Gao, P., Zhang, G. (2017). Auditing standards, professional judgment, and audit quality.Working paper. University of Chicago and University of Minnesota. Retrieved from http://faculty.chicagobooth. edu/pingyang.gao/research/papers/ProfessionalJudgement.pdf

Ha, H. T. N. (2012). Membership, benefits and responsibilities when becoming a member of the International Audit Organization and lessons learned for Vietnam. Vietnamese Auditing Journal, 1, 45-48 (in Vietnamese).

Hai, D. H., \& Trung, N. S. (2015). The factors affect the quality of financial statements audit in Vietnam businesses. Asian Social Science, 11(27), 172-181. https://doi.org/10.5539/ass.v12n1p172

Hai, P. T. (2014). Setting up the model of independent auditing in Vietnam to improve the quality and efficiency of operations in the context of integration (PhD Thesis). University of Economics Ho Chi Minh City, Vietnam (in Vietnamese).

Hai, P. T. (2016). The research of factors affecting the quality of audit activities: Empirical evidence in Vietnam. International Journal of Business and Management, 11(3), 83-94. https://doi.org/10.5539/ijbm.v11n3p83

Hai, P. T. (2017). Solutions to improve quality and effectiveness of independent auditing activities in Vietnam. International Journal of Economic Research, 14(15), 113-124. Retrieved from http://serialsjournals.com/articlesview.php?volumesno_id=1399\&article_id=22169\&volumes_ id=1068\&journals_id=41 
Hair, J. F., Black, W. C., Babin, B. J., \& Anderson, R. E. (2006). Multivariate data analysis (6th ed.). Analysis. Englewood Cliffs, NJ: Prentice Hall.

Hoseinbeglou, S., Masrori, R., \& Asadzadeh, A. (2013). The effect of corporate governance mechanisms on audit quality. Journal of Basic and Applied Scientific Research, 3(1), 891-897. Retrieved from https://www.textroad.com/pdf/JBASR/J.\%20Basic.\%20Appl.\%20Sci.\%20Res.,\%203(1)891-897,\%20 2013.pdf

Hu, L., \& Bentler, P. M. (1999). Cutoff criteria for fit indexes in covariance structure analysis: Conventional criteria versus new alternatives. Structural Equation Modeling: A Multidisciplinary Journal, 6(1), 1-55. https://doi.org/10.1080/10705519909540118

Kasim, N., Hashim, N. A. B., \& Salman, S. A. (2016). Conceptual relationship between corporate governance and audit quality in Shariah compliant companies listed on Bursa Malaysia. Modern Applied Science, 10(7), 106-114. https://doi.org/10.5539/mas.v10n7p106

Lam, T. K. (2011). Setting up a quality control mechanism for independent auditing activities in Vietnam (PhD Thesis). University of Economics Ho Chi Minh City, Vietnam (in Vietnamese).

Lee, C.-C. (2008). Effects of size on operating result of audit firms with strategic alliances: An empirical study. International Journal of Management, 25(4), 706-721, 779. Retrieved from https://search. proquest.com/openview/978a176c0c64167b5502240f45c46f88/1?pq-origsite=gscholar\&cbl=5703

Lennox, C. (2005). Management ownership and audit firm size. Contemporary Accounting Research, 22(1), 205-277. https://doi.org/10.1506/K2CG-U6V0-NPTC-EQBK

Mautz, R. \& H. A. S. (1961). The philosophy of auditing, American Accounting Association, Madison.

Pham, H., Amaria, P., Bui, T., \& Tran, S. (2014). A study of audit quality in Vietnam. International Journal of Business, Accounting \& Finance, 8(2), 73-110. Retrieved from https://web.a.ebscohost. $\mathrm{com} /$ abstract direct $=$ true \&profile $=$ ehost $\&$ scope $=$ site \&authtype $=$ crawler\&jrnl=1936699X\&AN=99 771210\&h=inhEa4qbiAiJtYcHYcNwttYMD1wB\%2blCOEu5hBmM\%2biY8NIOZKU\%2bLe0JEUW Uu8WrBqzJ\%2fgRvRJcmExJPPPkq672w\%3d\%3d\&crl=c\&resultNs=AdminWebAuth\&resultLocal= ErrCrlNotAuth\&crlhashurl=login.aspx\%3fdirect\%3dtrue\%26profile\%3dehost\%26scope\%3dsite\%26 authtype\%3dcrawler\%26jrnl\%3d1936699X\%26AN\%3d99771210

Pham, N. K., Duong, H. N., Pham, T. Q., \& Ho, N. T. T. (2017). Audit firm size, audit fee, audit reputation and audit quality: The case of listed companies in Vietnam. Asian Journal of Finance \& Accounting, 9(1), 429-447. https://doi.org/10.5296/ajfa.v9i1.10074

Rahmina, L. Y., \& Agoes, S. (2014). Influence of auditor independence, audit tenure, and audit fee on audit quality of members of capital market accountant forum in Indonesia. Procedia - Social and Behavioral Sciences, 164, 324-331. https://doi.org/10.1016/j.sbspro.2014.11.083

Schumacker, R. E., \& Lomax, R. G. (2004). A beginner's guide to structural equation modeling (2nd ed.). Lawrence Erlbaum Associates, Publishers, Mahwah, New Jersey, London. https://doi.org/10.4324/9781410610904

Seyed M. H. (2014). Effects of corporate governance on audit quality (MA Thesis). Universidade de Aveiro. Retrieved from https://ria.ua.pt/bitstream/10773/13423/1/Efeitos\%20do\%20governo\%20 das\%20sociedades\%20na\%20qualidade\%20da\%20auditoria.pdf

Suseno, N. S., \& Nofianti, L. (2018). Empirical evidence of audit firm size toward audit quality and reputation of public accounting firm. Advanced Science Letters, 24(5), 3327-3331(5). https://doi.org/10.1166/asl.2018.11367

Tan, T. T. G. (2009). External quality control of independent auditing activities [Kiểm soát chất lượng từ bên ngoài đối với hoạt động kiểm toán độc lập] (1rst ed.). Financial Publishing House, Ho Chi Minh City, Vietnam (in Vietnamese).

Thuy, B. T. (2014). Study the factors affecting the quality of auditing the financial statements of enterprises listed on the Vietnam securities market ( $\mathrm{PhD}$ Thesis). National Economics University, Vietnam (in Vietnamese). 
Tran, P., Tran, V. T., Dinh, T. C., \& Pham, T. K. A. (2018). Auditors' behavior impact on the quality of auditing - experimental research in Hochiminh city. In Proceedings of the International Conference on Finance, Accounting and Auditing (ICFAA 2018). Hanoi, Vietnam (pp. 528-539). Retrieved from https://drive.google.com/drive/u/0/folders/10r9MlWVothJxGPagYv_Cfez5K19OwU3a?fbclid=IwA R29bq3yZlfBmjArMADYVr7dpyxDLJNmXciTp_cILrbfWaRkk_ymBYRl3Gw

Tuan, N. A. (2014). Quality control audit of independent audit - current situation and complete solution (PhD Thesis). Academy of Finance, Vietnam (in Vietnamese).

VACPA. (2010-2017). Review report of 2010-2017 activities and direction of operation in 2011-2018 by independent auditors (in Vietnamese).

Zhan Shu, S. (2000). Auditor resignations: Clientele effects and legal liability. Journal of Accounting and Economics, 29(2), 173-205. https://doi.org/10.1016/S0165-4101(00)00019-7

Zureigat, Q. (2011). The effect of ownership structure on audit quality: Evidence from Jordan. International Journal of Business and Social Science, 2(10), 38-46. Retrieved from http://www.ijbssnet.com/ journals/Vol.\%202_No._10\%3B_June_2011/6.pdf 